\title{
DEUTSCHE DOME
}





\title{
Barouffitden in Iltbayern und Sdimaben
}

\author{
aufgenommen bon \\ WALTER HEGE \\ befdrieben von \\ GUSTAV BARTHEL
}

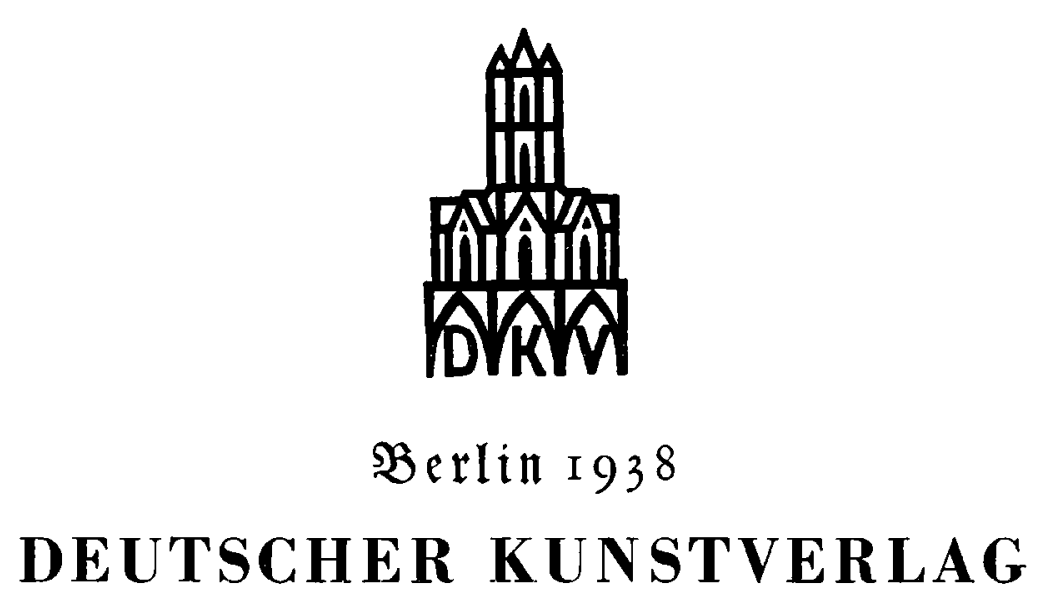

